\title{
Extracellular adenosine-mediated modulation of regulatory T cells
}

\section{Akio Ohta* and Michail Sitkovsky}

New England Inflammation and Tissue Protection Institute, Northeastern University, Boston, MA, USA

Extracellular adenosine-dependent suppression and redirection of pro-inflammatory activities are mediated by the signaling through adenosine receptors on the surface of most immune cells. The immunosuppression by endogenously-produced adenosine is pathophysiologically significant since inactivation of A2A/A2B adenosine receptor (A2AR/A2BR) and adenosineproducing ecto-enzymes CD39/CD73 results in the higher intensity of immune response and exaggeration of inflammatory damage. Regulatory T cells (Treg) can generate extracellular adenosine, which is implicated in the immunoregulatory activity of Tregs. Interestingly, adenosine has been shown to increase the numbers of Tregs and further promotes their immunoregulatory activity. A2AR-deficiency in Tregs reduces their immunosuppressive

\section{Edited by:}

Ellis L. Reinherz, Dana-Farber Cancer Institute, USA

Reviewed by:

Herman Waldmann, University of

Oxford, UK

Ellis L. Reinherz, Dana-Farber Cancer Institute, USA

${ }^{*}$ Correspondence:

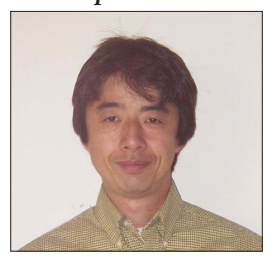

Akio Ohta is Principal Research Scientist at the Northeastern University. He came to NEU in 2004 after working at National Institute of Allergy and Infectious Diseases, National Institutes of Health for 4 years as a Visiting Fellow. At NEU, he has been working in the New England Inflammation and Tissue Protection Institute with his former lab chief at NIH, Dr. Michail Sitkovsky. Dr. Ohta received Ph.D. (Pharmaceutical Sciences) from Tohoku University, Japan in 1998. Since then, T cell immunology, cancer immunology, and immunoregulation have been among his research fields. a.ohta@neu.edu efficacy in vivo. Thus, adenosine is not only directly and instantly inhibiting to the immune response through interaction with $\mathrm{A} 2 \mathrm{AR} / \mathrm{A} 2 \mathrm{BR}$ on the effector cells, but also adenosine signaling can recruit other immunoregulatory mechanisms, including Tregs. Such interaction between adenosine and Tregs suggests the presence of a positive feedback mechanism, which further promotes negative regulation of immune system through the establishment of immunosuppressive microenvironment

Keywords: adenosine,A2A-adenosine receptor, A2B-adenosine receptor, regulatoryT cell, immunosuppression, tumor microenvironment

\section{INTRODUCTION}

Although efficient elimination of pathogens is attributable to the positive feedback nature of immune activation, immune cells also have negative feedback mechanisms that would limit the extent of expansion and effector functions of immune cells. The downregulation of immune response could be not only a homeostatic mechanism, but also an important reaction in protecting vital tissues from non-specific inflammatory damage. Therefore, when the pathogens are cleared, the positive feedback loop of the immune system needs to be broken to save healthy tissues from unnecessary collateral damage. Such endogenous mechanisms terminating inflammation have been a target of research and drug development to modulate the intensity of inflammation.

There are different classes of endogenous anti-inflammatory mechanisms ranging from molecules as small as carbon monoxide to professional suppressor cells including regulatory $\mathrm{T}$ cells (Treg) (Figure 1). Small molecules such as prostanoids and glucocorticoids are well-known negative regulators of immune response and are clinically important due to their pharmacological properties. Negative regulators such as anti-inflammatory cytokines (IL-10 and TGF-beta) and cellular proteins [indoleamine-2,3-dioxygenase (IDO), CTLA-4, and PD-1] represent the focus of extensive studies for the last several decades $(1,2)$. Indeed, blockade of CTLA-4 and PD-1 has currently progressed 


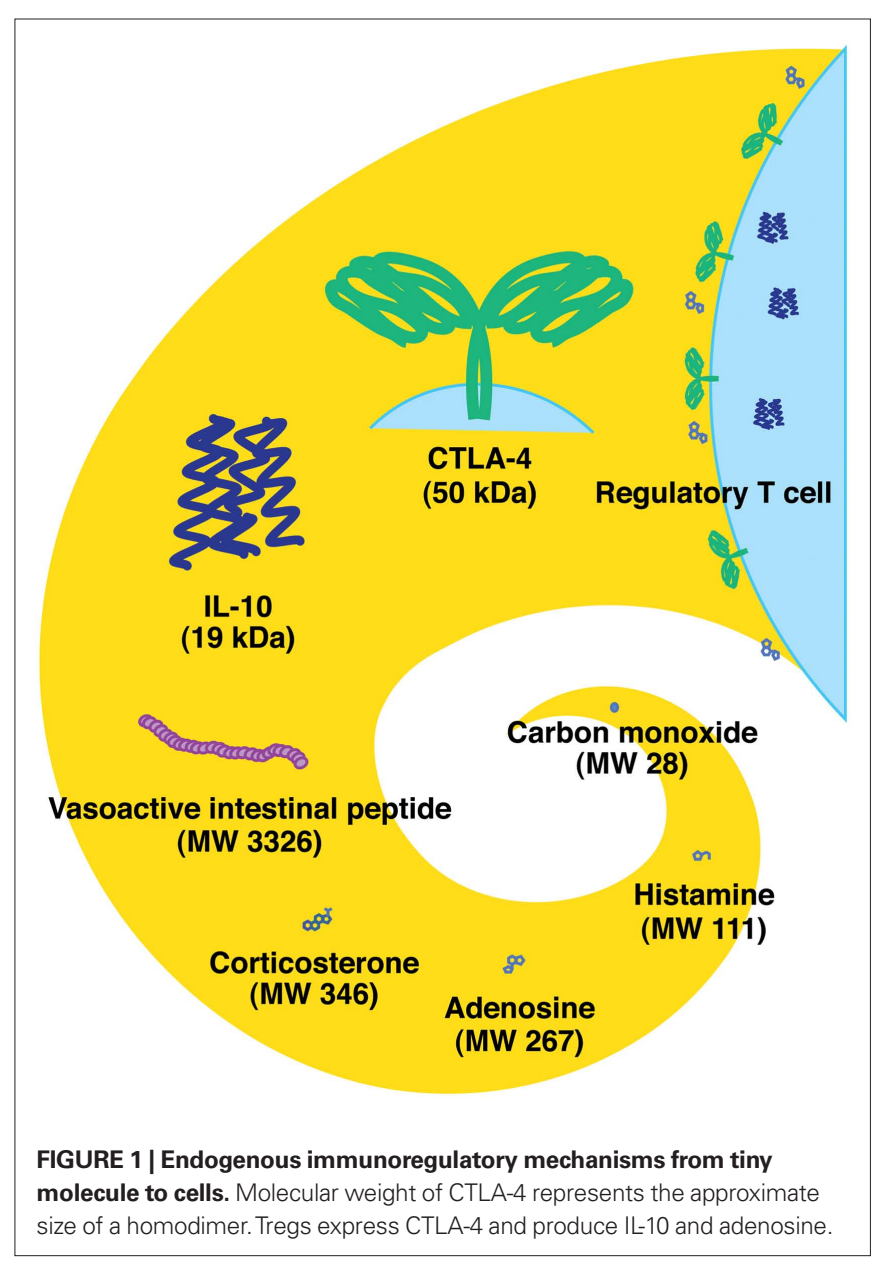

into promising cancer treatments $(3,4)$. Some negative regulators of immune response may be produced in response to stress. Extracellular adenosine represents a physiological negative regulator, which increases as a result of metabolic change during hypoxic stress. The intensive interest to adenosine-dependent immunoregulation developed relatively recently.

\section{KEY CONCEPT 1 | Extracellular adenosine}

In the intracellular compartment, adenosine represents an important component of energy metabolism and nucleic acid synthesis. However, extracellular adenosine plays a distinct role in the intercellular signaling via cell surface adenosine receptors.

\section{IMMUNOREGULATION BY ENDOGENOUS ADENOSINE}

The importance of adenosine receptor signaling has been recognized in the central nervous and cardiovascular systems $(5,6)$. Pharmacological studies of adenosine receptor signaling in the immune system have established that this pathway has immunosuppressive effects. In general, administration of adenosine or its analogs has been shown to block inflammation in various organs such as the liver, lung, kidney, heart, and digestive tract (7,8). A variety of inflammatory responses are susceptible to adenosine receptor agonists, especially those capable of stimulating A2A-adenosine receptor (A2AR) $(7,9)$.

A2AR is ubiquitously expressed in a wide variety of immune cells including T cells, B cells, NK cells, NKT cells, macrophages, dendritic cells, and granulocytes (Table $\mathbf{1}$ ). The strong anti-inflammatory
Table 1 | Adenosine receptor expression in immune cells and signaling pathway.

\begin{tabular}{|c|c|c|c|c|}
\hline & A1 & A2A & A2B & A3 \\
\hline Distribution & $\begin{array}{l}\text { Dendritic } \\
\text { cells } \\
\text { Macropha- } \\
\text { ges } \\
\text { Neutrophils }\end{array}$ & $\begin{array}{l}\text { Dendritic } \\
\text { cells } \\
\text { Macrophages } \\
\text { Neutrophils } \\
\text { Mast cells } \\
\text { T cells } \\
\text { NK cells } \\
\text { NKT cells }\end{array}$ & $\begin{array}{l}\text { Dendritic } \\
\text { cells } \\
\text { Macropha- } \\
\text { ges } \\
\text { Mast cells }\end{array}$ & $\begin{array}{l}\text { Dendritic } \\
\text { cells } \\
\text { Macrophages } \\
\text { Neutrophils } \\
\text { Mast cells }\end{array}$ \\
\hline $\begin{array}{l}\text { Signal } \\
\text { transduc- } \\
\text { tion }\end{array}$ & $\begin{array}{l}\mathrm{Gi} \\
\mathrm{CAMP} \downarrow \\
\mathrm{PLC} \uparrow\end{array}$ & $\begin{array}{l}\text { Gs } \\
\text { cAMP } \uparrow\end{array}$ & $\begin{array}{l}\mathrm{Gs} / \mathrm{Gq} \\
\mathrm{cAMP} \uparrow \\
\mathrm{PLC} \uparrow\end{array}$ & $\begin{array}{l}\mathrm{Gi} \\
\mathrm{CAMP} \downarrow \\
\mathrm{PLC} \uparrow\end{array}$ \\
\hline
\end{tabular}

function of A2AR implied a possible involvement of its natural ligand, endogenously formed adenosine, in the spontaneous control of immune response. This concept was conclusively proven using A2AR-deficient mice in which the induction of acute hepatitis inflicted much more severe inflammatory tissue damage than in wild-type controls (10). Importantly, the study showed that the lack of A2AR, despite other functional anti-inflammatory mechanisms, was sufficient to exaggerate inflammation, indicating the non-redundant significance of extracellular adenosine in the selfcontrol of inflammatory activities. Exacerbation of various types of inflammation in A2AR-deficient mice generalized the A2ARdependent control of inflammation (11-14).

Metabolic changes during inflammation favor the increase of extracellular adenosine (discussed in the next chapter). Inflammation destroys pathogens along with damage to surrounding tissue. In response, adenosine produced from the damaged tissue can suppress proinflammatory activities and prevent further damage. In inflamed and severely hypoxic tissues, local adenosine levels can reach high enough to activate not only A2AR but also low-affinity receptors such as $\mathrm{A} 2 \mathrm{~B}$-adenosine receptor (A2BR) (15-17). In many instances, the effect of A2BR stimulation is also immunosuppressive as shown by the inhibition of inflammatory tissue injury by A2BR agonist and by exaggerated inflammation in A2BR-deficient mice $(16,17)$. A2BR plays a distinctive role in controlling inflammation, e.g., induction of tolerogenic antigenpresenting cells (APC) by alternative activation $(18,19)$. Thus, the

\section{KEY CONCEPT 2 | Alternative activation}

Alternatively activated macrophages are those activated in aTh2-type cytokine milieu. However, this term is more widely used to represent anti-inflammatory macrophages including those induced in the presence of IL-10, TGF- $\beta$ or glucocorticoids. Alternatively activated macrophages are involved in resolution of inflammation and tissue remodeling.

inflammation-related increase of extracellular adenosine initiates negative feedback responses via A2AR and A2BR. The adenosineA2AR/A2BR pathway serves as an indispensable immunoregulatory mechanism that regulates the extent of immune response.

\section{WHERE EXTRACELLULAR ADENOSINE COMES FROM}

Dephosphorylation of ATP results in adenosine formation. In the extracellular compartment, this metabolism is mediated by ecto-5' -nucleotidases, i.e., CD39 and CD73. CD39 catalyzes degradation of ATP to AMP, and CD73 further converts AMP 


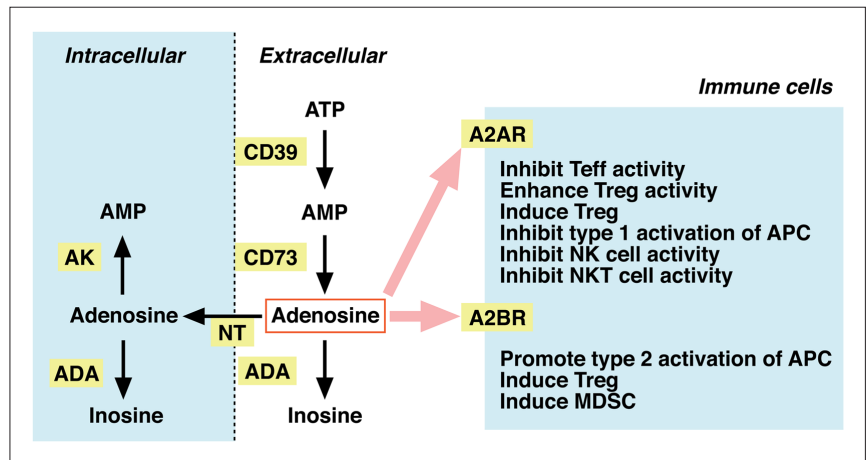

FIGURE 2 | Metabolism of extracellular adenosine and its effect on cellular immunity. The activities of CD39 and CD73 produce extracellular adenosine. Extracellular adenosine decreases by adenosine deaminase (ADA)-dependent catabolism and by cellular uptake through nucleoside transporters (NT). Adenosine in the intracellular compartment is converted to AMP by adenosine kinase (AK) or catabolized by ADA. When extracellular levels of adenosine increase, it stimulates A2AR (high-affinity) and A2BR (low-affinity) on immune cells. Adenosine is suppressive to effectorT (Teff), NK, and NKT cells. The immunosuppressive activity may be further enhanced by adenosine-mediated induction of Tregs, tolerogenic antigen-presenting cells (APC), and myeloid-derived suppressor cells (MDSC).

to adenosine (Figure 2). Extracellular adenosine may be taken up to the intracellular compartment through nucleoside transporters on the plasma membrane, or it may be metabolized to inosine by adenosine deaminase (ADA). Intracellular adenosine may be re-phosphorylated to AMP by the activity of adenosine kinase. Extracellular adenosine concentration is largely reduced in mice lacking CD73, suggesting that degradation of adenine nucleotides is responsible for the production of extracellular adenosine $(20,21)$. In contrast, inhibitors of ADA and nucleoside transporters increased extracellular adenosine, suggesting the importance of these pathways in the removal of extracellular adenosine $(22,23)$.

Extracellular adenosine levels are known to increase in the event of inflammation $(11,24-26)$. This increase may be associated with the release of adenosine and adenine nucleotides in inflamed tissues. Activated polymorphonuclear cells (PMN) were shown to release AMP, which contributed to adenosine increase after metabolism by CD73 (27). It is also likely that inflammatory tissue damage causes uncontrolled leakage of adenine nucleotides from critically damaged cells. Skin irritant was shown to induce ATP and ADP release from keratinocytes (28).

Inflammatory tissue damage, especially damage on vasculature, disturbs blood flow resulting in a diminished oxygen supply. In addition, a massive accumulation of inflammatory effector cells increases local oxygen demand. The deficit in oxygen supply and the increase in oxygen demand cause local hypoxia in inflamed tissue. Tissue hypoxia seems to be conductive to the increase of extracellular adenosine concentration. Hypoxia is known to induce CD39 and $\operatorname{CD} 73(29,30)$ but to inhibit adenosine kinase $(31,32)$. The increase of adenosine formation and the decrease of removal thus favor adenosine accumulation under hypoxia. Adenosine can also positively regulate CD73 expression and further enhance adenosine formation (33).
Since formation of extracellular adenosine is crucial to downregulation of inflammatory responses, deficiency in adenosine metabolism should affect the intensity of inflammation. Exaggerated inflammation in CD39-deficient and CD73-deficient mice suggested that degradation of extracellular adenine nucleotides by CD39 and CD73 is a major source of adenosine for limiting inflammation (34-37). Similarly, further metabolism of adenosine plays a significant role in controlling the extracellular concentration of adenosine. Inhibitors of ADA and adenosine kinase promote adenosine increase and consequently suppress inflammation (22, $23,38)$. The anti-inflammatory effect was also evident after the inhibition of cellular adenosine uptake by nucleoside transporters (39).

\section{ADENOSINE PRODUCTION AS A MECHANISM OF IMMUNOREGULATION BY REGULATORY T CELLS}

Regulatory T cells are a subset of CD4 ${ }^{+} \mathrm{T}$ cells expressing CD25 and FoxP3, a transcriptional factor, which regulates the immunosuppressive activity of Tregs. Immunoregulation offered by Tregs is critically

\section{KEY CONCEPT 3 | FoxP3}

Forkhead box P3 (FoxP3) is a transcription factor that is crucial for development and immunoregulatory function of Tregs. FoxP3 expression is often regarded as a signature of Tregs, especially in mice.

important because the lack of Treg leads to the pathogenesis of autoimmune disorders $(40,41)$. Tregs have various immunosuppressive molecules including TGF- $\beta$, IL-10, CTLA- 4 , and galectin- 1 , although it is still unclear, which mechanism is the most important for the immunoregulatory activity. Among these mechanisms, Tregs were found to actively produce extracellular adenosine and block activation of effector cells through A2AR $(42,43)$.

Unlike conventional resting $\mathrm{T}$ cells, Tregs were found to express both CD39 and CD73 at high levels (44-46). These nucleotidases on the surface of Tregs were enzymatically active, therefore, Tregs were capable of producing extracellular adenosine from ATP. Since inhibitors of CD39 and CD73 reduced the immunoregulatory activity of Tregs $(44,47,48)$, production of adenosine was suggested to represent, at least in part, the immunosuppressive mechanism of Tregs. Tregs were less efficient against A2AR-deficient effector T cells or in the presence of A2AR antagonist $(45,47)$. These results indicate that adenosine produced from Tregs executes immunosuppression by triggering A2AR-dependent inhibition of effector cell activation. This mechanism is functional in both mice and human Tregs. Human T cells from older people tend to produce larger amount of extracellular adenosine compared to those obtained from younger subjects (49). It might be interesting to study adenosine-dependent immunoregulation by Tregs from the point of view of immunosenescence.

Upon interaction with A2AR, adenosine increases cAMP levels, and subsequent activation of protein kinase $\mathrm{A}$ is responsible for the inhibition of cell activation. When Tregs suppress immune response, an increase of cAMP is observed in the target cells $(50,51)$. Other mechanisms triggering cAMP increase may be also involved in the immunoregulatory activity of Tregs. Indeed, Tregs express cyclooxygenase-2 (COX-2) and produce $\mathrm{PGE}_{2}$, which stimulates cAMP production in target cells $(52,53)$. Along with adenosine, $\mathrm{PGE}_{2}$ from Tregs was found to play a role in the immunoregulatory activity of Tregs. 
Biological significance of adenosine-dependent immunoregulation by Tregs was demonstrated in various in vivo models of inflammatory disorders. While adoptive transfer of wild-type Tregs strongly attenuates inflammation, the transfer of CD73-deficient Tregs could not prevent inflammation including gastritis, acute lung inflammation, ischemia-reperfusion injury, and graft-versus-host disease (14, 48, 54, 55). Similarly, Tregs lacking CD39 failed to block T cell infiltration in contact hypersensitivity (56). In humans, Tregs from AIDS patients and cancer patients express CD39 and CD73 at higher levels than healthy subjects, suggesting adenosine production from Tregs during immunosuppression in humans (57). This evidence increasingly emphasizes the significance of adenosine-producing activity among a variety of immunoregulatory mechanisms of Tregs.

\section{REGULATION OF TREG ACTIVITY BY ADENOSINE}

When the first paper reported adenosine production from Treg, the other group reported an in vivo study, which might implicate roles of A2AR in Treg functions (58). In that study, colitis induction by $\mathrm{CD} 4^{+} \mathrm{CD} 45 \mathrm{RB}^{\text {hi }}$ naïve T cells and the preventive effect of $\mathrm{CD} 4^{+}$ CD45RB ${ }^{\text {low }}$ cells were examined using $\mathrm{T}$ cells derived from wildtype and A2AR-deficient mice. Co-transfer of $\mathrm{CD}^{+}{ }^{+} \mathrm{CD} 45 \mathrm{RB}^{\text {low }}$ cells, which contain Tregs, blocked $\mathrm{CD} 4^{+} \mathrm{CD} 45 \mathrm{RB}{ }^{\text {hi }}$ cell-induced pathogenesis; however, colitis by A2AR-deficient $\mathrm{CD} 4^{+} \mathrm{CD} 45 \mathrm{RB}^{\text {hi }}$ cells was resistant to the preventive effect of $\mathrm{CD} 4^{+} \mathrm{CD} 45 \mathrm{RB}^{\text {low }}$ cell co-transfer. Having been published before the identification of adenosine-producing activity in Tregs, the data might have been enigmatic at that time. Retrospectively, this report might imply immunoregulatory activity of adenosine produced by Tregs presented in $\mathrm{CD}^{+} \mathrm{CD}^{+} 5 \mathrm{RB}^{\text {low }}$ fraction. However, the paper presented other puzzling data indicating that A2AR-deficient CD4 ${ }^{+}$ $\mathrm{CD} 45 \mathrm{RB}^{\text {low }}$ cells were not as effective as wild-type $\mathrm{CD} 4^{+} \mathrm{CD} 45 \mathrm{RB}^{\text {low }}$ cells in preventing colitis. Was this data implying that A2AR expression was essential to full activation of Tregs?

It was hypothesized that activity of Tregs might be under control of tissue oxygen tension and extracellular adenosine levels (59). Based on the presence of consensus sequences of hypoxiaresponsive element and cAMP-responsive element in the promoter region of anti-inflammatory molecule genes, it was speculated that hypoxia and adenosine would be responsible for the regulation of immunosuppressive activity of Tregs. Although the effect of hypoxia on Tregs is still arguable (60-63), the speculation was

\section{KEY CONCEPT 4 | Effect of hypoxia on Tregs}

Hypoxia has been reported to induce FoxP3 in T cells and increase Treg abundance. Such changes are mediated by HIF-1 $\alpha$. However, other reports demonstrated downregulation of Tregs in the presence of $\mathrm{HIF}-1 \alpha$, suggesting a complicated role of HIF-1 $\alpha$ for Tregs.

proven to be true at least for the adenosine part. When T cells were stimulated with allogenic cells (mixed lymphocyte culture), A2AR agonist strongly inhibited activation of cytotoxic effector $\mathrm{T}$ cells. However, in the same cell culture, A2AR agonist massively increased the $\mathrm{CD}^{+}{ }^{+} \mathrm{FoxP}^{+}$population (64). Supporting the hypothesis above, those Tregs expanded in the presence of A2AR stimulation demonstrated an increase in CTLA-4 expression and a significantly stronger immunoregulatory activity (64). Consistent with this observation, pretreatment of Tregs with A2AR agonist before cell transfer enhanced their efficacy in vivo in the prevention of ischemia-reperfusion injury. Moreover, A2AR-deficient Tregs were found to be less efficacious in protecting tissues from inflammatory damage, suggesting that endogenous adenosine positively controls the immunoregulatory activity of Tregs in vivo (48). A2AR-dependent expansion of Tregs may be important in suppressing inflammatory disorders such as graft-versus-host disease and experimental autoimmune uveitis because the induction of immunoregulatory activity required $\mathrm{A} 2 \mathrm{AR}$ expression $(65,66)$.

The enhancement of immunoregulatory activity may be due to cAMP increase by A2AR stimulation. HIVgp120 binds to CD4 on human Tregs and stimulates immunoregulatory function. This reaction is mediated by the increase of cAMP in Tregs (67). Stimulation of $\beta_{2}$-adrenergic receptor, which also induces cAMP, can enhance Treg activity as it was observed with A2AR stimulation (68). Conversely, immunoregulatory activity of Tregs attenuates after treatments reducing cAMP levels, e.g., adenylate cyclase inhibition or activation of cAMP phosphodiesterase (69-71). Mechanisms for adenosine-mediated promotion of Treg activity may include recruitment of other anti-inflammatory mechanisms. For instance, COX-2 is inducible by A2AR stimulation to produce potentially anti-inflammatory metabolite $\mathrm{PGE}_{2}$ (72). Although A2AR-dependent induction is not directly demonstrated in Tregs, COX-2 is one of the immunosuppressive mechanisms of Tregs as discussed in the previous chapter.

Tregs develop in the thymus (natural Treg) or in the periphery by inducing functional differentiation from conventional $\mathrm{T}$ cells (inducible Treg) $(40,41)$. A2AR stimulation enhanced not only proliferation of natural Tregs but also induction of new Tregs from FoxP3- $\mathrm{T}$ cells (64). T cell stimulation in the presence of A2AR agonist induced FoxP3 and LAG3 mRNA in T cells, suggesting newly induced Tregs (73). A2AR agonist further enhanced development of inducible Tregs by TGF- $\beta$ (65). In addition to A2AR, A2BR also plays a role in the induction of Tregs. Agonist of A2BR promoted, but A2BR-deficiency prevented, Treg induction (74). In human Tregs, vasoactive intestinal peptide (VIP) was shown to promote Treg induction via cAMP (75). It is possible that the adenosine-dependent induction of Tregs may be again mediated by cAMP induction.

Thus, Tregs not only utilize adenosine as one of their immunosuppressive mechanisms, but also receive positive regulation from adenosine to enhance the number and immunosuppressive activity of Tregs (Figure 3). Since both Tregs and adenosine modify immune response in the negative direction, it seems reasonable that these two elements are mutually enhancing their production and activity.

\section{MODULATION OF TREG ACTIVITY THROUGH THE INTERVENTION TO ADENOSINE-A2AR PATHWAY}

Excess adenosine in ADA deficiency causes a detrimental effect on immune cells and results in severe combined immunodeficiency. Pegylated ADA (PEG-ADA) has been used for treatment by decreasing adenosine levels in these patients. A recent report suggested a decrease of Treg activity in mice and humans after treatment with PEG-ADA (76). It may be possible to manipulate Treg activity in vivo through intervention in the adenosine-A2AR pathway.

Conversely, adenosine-producing CD73 is inducible by TGF- $\beta$ (77). TGF- $\beta$ induces Tregs, and the increase of adenosine-producing activity may contribute to the enhancement of immunoregulatory 


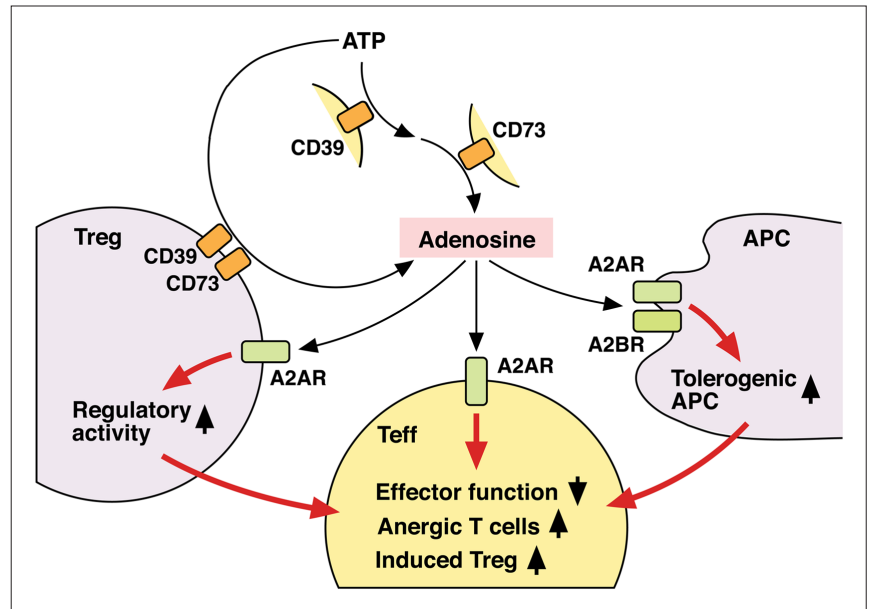

FIGURE 3 | Mechanisms of T cell regulation by extracellular adenosine. Extracellular adenosine can be produced by activities of CD39 and CD73 on cell surface. And its interaction with A2AR directly inhibits T cell activation. Tregs express both CD39 and CD73 at high levels and use adenosine for their immunoregulatory activity. Adenosine enhances immunoregulatory activity of Tregs via A2AR signaling. A2AR signaling in effectorT cells may induce differentiation into Tregs. There might be a positive feedback loop between adenosine and Treg-dependent immunoregulation. Moreover, adenosine increases tolerogenic APCs, which are poor stimulators of effectorT cells. Thus, adenosine suppresses T cell immunity both by directly inhibiting activation of effector T cells and indirectly by producing the immunosuppressive environment. By employing different mechanisms, the immunosuppression by adenosine might be quickly effective and persistent.

activity of the induced Tregs. In addition to the induction of Tregs, this cytokine is also involved in functional differentiation of naïve $\mathrm{CD}^{+} \mathrm{T}$ cells into Th17 cells. Although Th17 cells have been known for their proinflammatory activities, they indeed express CD39 and CD73 and are capable of suppressing T cell activation by producing adenosine (78). Interestingly, such function was found only in Th17 cells induced by TGF- $\beta$ + IL- 6 , whereas those induced in the absence of TGF- $\beta$ were not immunosuppressive. CD73-inducing activity of TGF- $\beta$ may be responsible for this difference. In addition to TGF- $\beta$, various agents including triiodothyronine (T3), IFN$\alpha$, indomethacin, and rosuvastatin are capable of inducing CD73 (79-82). Interestingly, anti-inflammatory action of some clinical medications is explained by the increase of adenosine. Methotrexate $(83,84)$ and sulfasalazine $(85,86)$ can increase adenosine concentration high enough to suppress inflammatory response through A2AR. This increase in adenosine is dependent on CD73 activity. It is possible that clinical use of such agents promote immunoregulation by Tregs. Indeed, among these CD73 inducers, statins were shown to increase the number and function of Tregs $(87,88)$.

The promotion of Treg-dependent immunoregulation should be beneficial to alleviate many inflammatory disorders and to facilitate successful tissue transplantation $(89,90)$. In hematopoietic stem cell transplantation, transfer of Tregs should be able to suppress graft-versus-host disease, which is caused by the attack of recipientderived lymphocytes to the host cells and is occasionally lethal (90, 91). Adenosine receptor stimulation will be useful to increase the recovery of Tregs during in vitro expansion and to promote their efficacy after the transfer.
While immunoregulation by Tregs is crucial to prevent autoimmunity, ironically, the same mechanism benefits tumor tissue by providing protection against immune attack. Accumulation of Tregs represents the immunosuppressive nature of the tumor microenvironment, and elimination of Tregs improves

\section{KEY CONCEPT 5 |Tumor microenvironment}

It has long been a question why immunotherapy mightily struggles against tumors in vivo even with highly active immune cells. Tumors contain a number of immunosuppressive mechanisms and inactivate incoming anti-tumor immune cells. Countermeasure to the immunosuppression in tumor microenvironment is complementary to the current protocol of immunotherapy and is expected to improve tumor regression.

immunological tumor regression $(1,2,92)$. Adenosine was also demonstrated to accumulate in tumors $(93,94)$. Tissue hypoxia, which is conductive to the increase of extracellular adenosine levels, is not uncommon in tumors due to the disorganized proliferation of tumor cells and poor blood flow $(95,96)$. The significance of adenosine in tumors was demonstrated when A2AR-deficient mice, but not wild-type mice, underwent complete regression of solid tumor (94). The tumor-protective role of adenosine was further demonstrated by retarded growth or enhanced elimination of tumors in A2BR-deficient mice $(97,98)$ and CD73-deficient mice $(99,100)$. Adenosine can directly down-regulate effector functions of anti-tumor immune cells and may also indirectly suppress anti-tumor immune response by promoting Treg activities. Moreover, among other effects of adenosine is the preferential alternative activation of $\operatorname{APCs}(18,19)$ and induction of myeloid-derived suppressor cells (101), both of which lead to inactivation of immune cells. Wrapped in extracellular adenosine, tumor cells employ multiple mechanisms to evade anti-tumor immune response.

\section{KEY CONCEPT 6 | Myeloid-derived suppressor cells}

A population of myeloid-derived suppressor cells (MDSCs) includes immature forms of macrophages, granulocytes and dendritic cells. MDSCs express immunosuppressive molecules (arginase and reactive oxygen/nitrogen species) and strongly suppress T-cell activities.

Maintaining the capability of eliminating cancer cells by host immune cells is a great advantage in the effective treatment of cancer. Anti-tumor immunity is expected to have a positive impact either alone or complementary to surgical removal of the tumor mass because immune cells should be able to seek out and destroy hidden and metastatic cancer cells. Improving anti-tumor $\mathrm{T}$ cell activity by A2AR antagonists $(94,102,103)$ and CD73 inhibitors $(102,104)$ suggests promise for disengaging the adenosine-mediated immunosuppression in the tumor microenvironment.

Thus, intensity of inflammation may be manipulated by intervening in the adenosine-A2AR/A2BR pathway. The direction of manipulation, either inhibition or promotion, will be dependent on the nature of disease. Enhancement of the adenosine-mediated immunoregulation will be beneficial to treat inflammatory disorders such as acute lung injury, arthritis, inflammatory bowel diseases, and diseases accompanying ischemia-reperfusion injury. The same strategy may promote successful hematopoietic stem 


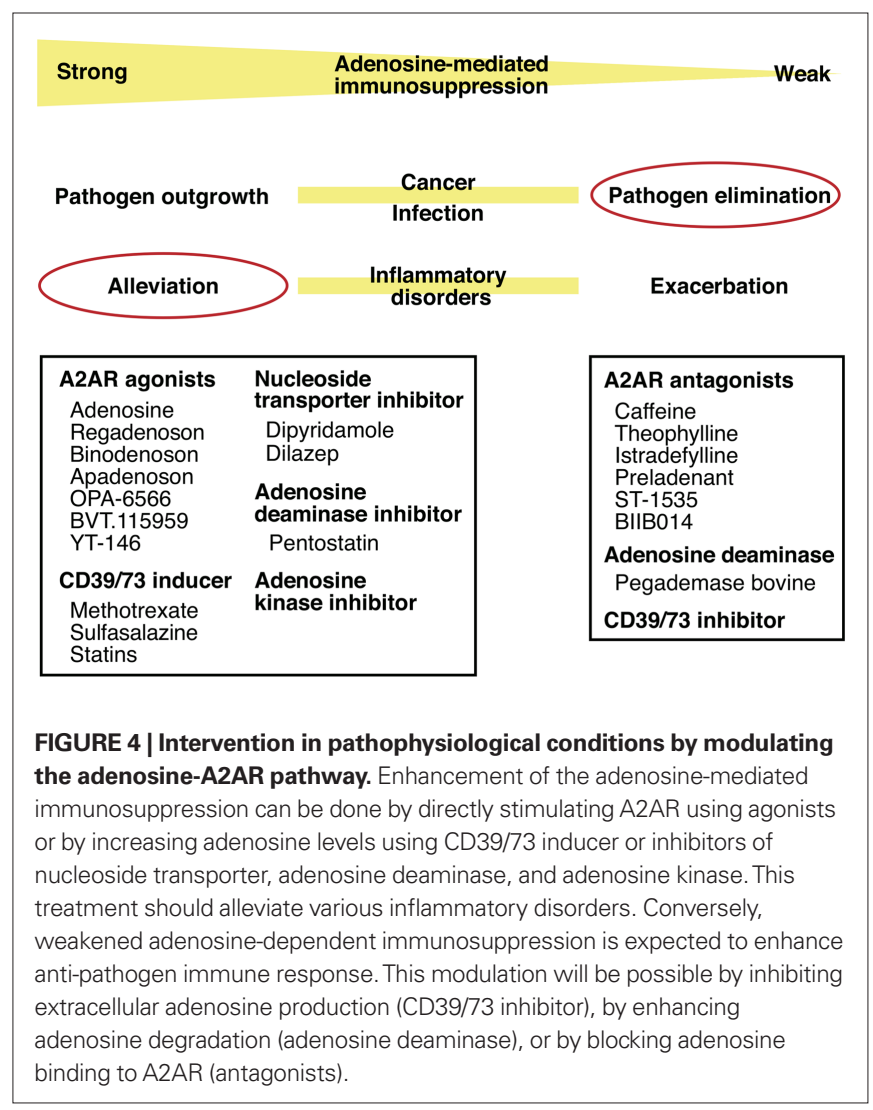

cell transplantation by blocking graft-versus-host reaction and tissue transplantation by inhibiting ischemia-reperfusion injury and allograft rejection. The inhibition of this mechanism will promote elimination of pathogen (Figure 4).

\section{MECHANISMS OF T CELL INHIBITION BY ADENOSINE}

The predominance of A2AR on T cells has been known for years (105), but it took some time before T cells attracted more attention as the important target of A2AR-mediated immunosuppression. A2AR agonists block $\mathrm{T}$ cell activation by interfering with $\mathrm{T}$ cell receptor signaling $(106,107)$, and they inhibit proliferation and effector functions of T cells such as cytotoxicity and cytokineproducing activity $(9,108,109)$. Experiments with purified CD4 ${ }^{+}$ and $\mathrm{CD}^{+} \mathrm{T}$ cells showed that stimulation of A2AR on T cells could directly suppress their activation (109). This direct action of adenosine can instantly suppress inflammatory responses in extensively damaged tissue to save the tissue from critical loss of function. Recent studies suggest that adenosine regulates $\mathrm{T}$ cell activities in different levels (Figure 3).

$\mathrm{T}$ cell activation in an adenosine-rich environment allows expansion of activated T cells lacking effector functions. Indeed, $\mathrm{T}$ cells activated in the presence of A2AR agonist could produce a small amount of IFN- $\gamma$ even after the removal of A2AR agonist (73, 109). The impairment of effector function was persistent in these T cells. Therefore, immunoregulation by adenosine is not simply an immunosuppressive effect in its very presence, but it imprints $\mathrm{T}$ cells with longer-lasting memory to the immunosuppressive signal, i.e., anergic T cells.
In addition, adenosine can induce APCs that are capable of producing immunosuppressive molecules such as TGF- $\beta$, IL-10, arginase, IDO, and COX-2 $(18,19)$. Induction of these molecules indicates alternative activation of APCs, which leads to the inhibition of T cell activation. While A2AR mediates inhibition of classical proinflammatory activation of APCs, A2BR may play a major role in the induction of alternative activation. Indeed, APCs stimulated in the presence of adenosine became a tolerogenic phenotype that is quite inefficient in producing effector T cells. Furthermore, adenosine may suppress antigen-specific activation of $\mathrm{T}$ cells by interfering with the migration of $\mathrm{T}$ cell and APCs in the draining lymph node (110).

As we discussed, adenosine promotes expansion of Tregs and their immunoregulatory activity. The rise of professional immunoregulatory cells would be of great importance in the adenosineinducible immunosuppressive environment. Immune activation in the presence of adenosine can establish a memory of exposure to the immunosuppressive signal.

Most of these cellular reactions to adenosine seem to be mediated by cAMP. Both A2AR and A2BR are coupled to Gs protein, and stimulation of these receptors can increase cAMP production by adenylate cyclase (Table 1). The increase of cAMP activates protein kinase A, but activation of Epac also happens at least after A2AR stimulation (111). The adenosine receptor signaling pathway that results in promotion of Treg activity is yet to be elucidated.

Research has revealed that adenosine is capable of regulating a wide range of immunoregulatory mechanisms. Notably, adenosine actively promotes Treg-mediated immunoregulation by increasing cell number and by enhancing their activity. Thus, immunosuppression by adenosine involves quick, counteractive, and direct inhibition of immune activation and long-term effect, e.g., anergic T cells, tolerogenic APCs, Tregs, and myeloid-derived suppressor cells. By evoking all these mechanisms, adenosine may play an important role in establishing an immunosuppressive environment, which can be seen in tumors. It is also interesting that adenosine acts as a regulator of other endogenous immunoregulatory mechanisms.

\section{ACKNOWLEDGMENTS}

The authors thank Susan Ohman and Robert Abbott for careful reading of this manuscript.

\section{REFERENCES}

1. Rabinovich GA, Gabrilovich D, Sotomayor EM. Immunosuppressive strategies that are mediated by tumor cells. Annu Rev Immunol (2007) 25:267-96. doi: 10.1146/ annurev.immunol.25.022106.141609

2. Mellor AL, Munn DH. Creating immune privilege: active local suppression that benefits friends, but protects foes. Nat Rev Immunol (2008) 8:74-80. doi: 10.1038/ nri2233

3. Fife BT, Bluestone JA. Control of peripheral T-cell tolerance and autoimmunity via the CTLA-4 and PD-1 pathways. Immunol Rev (2008) 224:166-82. doi: 10.1111/j.1600-065X.2008.00662.x

4. Okazaki T, Chikuma S, Iwai Y, Fagarasan S, Honjo T. A rheostat for immune responses: the unique properties of $\mathrm{PD}-1$ and their advantages for clinical application. Nat Immunol (2013) 14:1212-8. doi: 10.1038/ni.2762

5. Fredholm BB, Ap IJ, Jacobson KA, Klotz KN, Linden J. International Union of Pharmacology. XXV. Nomenclature and classification of adenosine receptors. Pharmacol Rev (2001) 53:527-52.

6. Fredholm BB, Ap IJ, Jacobson KA, Linden J, Muller CE. International Union of Basic and Clinical Pharmacology. LXXXI. Nomenclature and classification of adenosine receptors - an update. Pharmacol Rev (2011) 63:1-34. doi: 10.1124/pr.110.003285 
7. Eltzschig HK, Sitkovsky MV, Robson SC. Purinergic signaling during inflammation. N Engl J Med (2012) 367:2322-33. doi: 10.1056/NEJMra1205750

8. Chen JF, Eltzschig HK, Fredholm BB. Adenosine receptors as drug targets what are the challenges? Nat Rev Drug Discov (2013) 12:265-86. doi: 10.1038/ nrd3955

9. Sitkovsky MV, Lukashev D, Apasov S, Kojima H, Koshiba M, Caldwell C, et al. Physiological control of immune response and inflammatory tissue damage by hypoxia-inducible factors and adenosine A2A receptors. Annu Rev Immunol (2004) 22:657-82. doi: 10.1146/annurev.immunol.22.012703.104731

10. Ohta A, Sitkovsky M. Role of G-protein-coupled adenosine receptors in downregulation of inflammation and protection from tissue damage. Nature (2001) 414:916-20. doi: 10.1038/414916a

11. Thiel M, Chouker A, Ohta A, Jackson E, Caldwell C, Smith P, et al. Oxygenation inhibits the physiological tissue-protecting mechanism and thereby exacerbates acute inflammatory lung injury. PLoS Biol (2005) 3:e174. doi: 10.1371/journal. pbio. 0030174

12. Mohsenin A, Mi T, Xia Y, Kellems RE, Chen JF, Blackburn MR. Genetic removal of the $\mathrm{A} 2 \mathrm{~A}$ adenosine receptor enhances pulmonary inflammation, mucin production, and angiogenesis in adenosine deaminase-deficient mice. Am J Physiol Lung Cell Mol Physiol (2007) 293:L753-61. doi: 10.1152/ajplung.00187.2007

13. Nadeem A, Fan M, Ansari HR, Ledent C, Jamal Mustafa S. Enhanced airway reactivity and inflammation in $\mathrm{A} 2 \mathrm{~A}$ adenosine receptor-deficient allergic mice. Am J Physiol Lung Cell Mol Physiol (2007) 292:L1335-44. doi: 10.1152/ ajplung.00416.2006

14. Alam MS, Kurtz CC, Wilson JM, Burnette BR, Wiznerowicz EB, Ross WG, et al. A2A adenosine receptor (AR) activation inhibits pro-inflammatory cytokine production by human CD4+ helper T cells and regulates Helicobacter-induced gastritis and bacterial persistence. Mucosal Immunol (2009) 2:232-42. doi: 10.1038/mi.2009.4

15. Karhausen J, Haase VH, Colgan SP. Inflammatory hypoxia: role of hypoxia-inducible factor. Cell Cycle (2005) 4:256-8. doi: 10.4161/cc.4.2.1407

16. Hasko G, Csoka B, Nemeth ZH, Vizi ES, Pacher P. A(2B) adenosine receptors in immunity and inflammation. Trends Immunol (2009) 30:263-70. doi: 10.1016/j. it.2009.04.001

17. Koeppen M, Eckle T, Eltzschig HK. Interplay of hypoxia and A2B adenosine receptors in tissue protection. Adv Pharmacol (2011) 61:145-86. doi: 10.1016/ B978-0-12-385526-8.00006-0

18. Ben Addi A, Lefort A, Hua X, Libert F, Communi D, Ledent C, et al. Modulation of murine dendritic cell function by adenine nucleotides and adenosine: involvement of the A(2B) receptor. Eur J Immunol (2008) 38:1610-20. doi: 10.1002/ eji.200737781

19. Novitskiy SV, Ryzhov S, Zaynagetdinov R, Goldstein AE, Huang Y, Tikhomirov OY, et al. Adenosine receptors in regulation of dendritic cell differentiation and function. Blood (2008) 112:1822-31. doi: 10.1182/blood-2008-02-136325

20. Volmer JB, Thompson LF, Blackburn MR. Ecto-5' -nucleotidase (CD73)-mediated adenosine production is tissue protective in a model of bleomycin-induced lung injury. J Immunol (2006) 176:4449-58. doi: 10.4049/jimmunol.176.7.4449

21. Grenz A, Zhang H, Weingart J, Von Wietersheim S, Eckle T, Schnermann J, et al. Lack of effect of extracellular adenosine generation and signaling on renal erythropoietin secretion during hypoxia. Am J Physiol Renal Physiol (2007) 293:F1501-11. doi: 10.1152/ajprenal.00243.2007

22. Resta R, Hooker SW, Laurent AB, Jamshedur Rahman SM, Franklin M, Knudsen $\mathrm{TB}$, et al. Insights into thymic purine metabolism and adenosine deaminase deficiency revealed by transgenic mice overexpressing ecto- $5^{\prime}$-nucleotidase (CD73). J Clin Invest (1997) 99:676-83. doi: 10.1172/JCI119211

23. Tofovic SP, Zacharia L, Carcillo JA, Jackson EK. Inhibition of adenosine deaminase attenuates endotoxin-induced release of cytokines in vivo in rats. Shock (2001) 16:196-202. doi: 10.1097/00024382-200116030-00005

24. Driver AG, Kukoly CA, Ali S, Mustafa SJ. Adenosine in bronchoalveolar lavage fluid in asthma. Am Rev Respir Dis (1993) 148:91-7. doi: 10.1164/ajrccm/148.1.91

25. Nishiyama A, Miura K, Miyatake A, Fujisawa Y, Yue W, Fukui T, et al. Renal interstitial concentration of adenosine during endotoxin shock. Eur J Pharmacol (1999) 385:209-16. doi: 10.1016/S0014-2999(99)00716-5

26. Martin C, Leone M, Viviand X, Ayem ML, Guieu R. High adenosine plasma concentration as a prognostic index for outcome in patients with septic shock. Crit Care Med (2000) 28:3198-202. doi: 10.1097/00003246-200009000-00014

27. Lennon PF, Taylor CT, Stahl GL, Colgan SP. Neutrophil-derived 5' -adenosine monophosphate promotes endothelial barrier function via CD73-mediated conversion to adenosine and endothelial A2B receptor activation. J Exp Med (1998) 188:1433-43. doi: $10.1084 /$ jem.188.8.1433
28. Mizumoto N, Kumamoto T, Robson SC, Sevigny J, Matsue H, Enjyoji K, et al. CD39 is the dominant Langerhans cell-associated ecto-NTPDase: modulatory roles in inflammation and immune responsiveness. Nat Med (2002) 8:358-65. doi: $10.1038 / \mathrm{nm} 0402-358$

29. Synnestvedt K, Furuta GT, Comerford KM, Louis N, Karhausen J, Eltzschig HK, et al. Ecto-5' -nucleotidase (CD73) regulation by hypoxia-inducible factor-1 mediates permeability changes in intestinal epithelia. JClin Invest (2002) 110:993-1002. doi: 10.1172/JCI0215337

30. Deaglio S, Robson SC. Ectonucleotidases as regulators of purinergic signaling in thrombosis, inflammation, and immunity. Adv Pharmacol (2011) 61:301-32. doi: 10.1016/B978-0-12-385526-8.00010-2

31. Kobayashi S, Zimmermann H, Millhorn DE. Chronic hypoxia enhances adenosine release in rat $\mathrm{PC} 12$ cells by altering adenosine metabolism and membrane transport. J Neurochem (2000) 74:621-32. doi: 10.1046/j.1471-4159.2000.740621.x

32. Morote-Garcia JC, Rosenberger P, Kuhlicke J, Eltzschig HK. HIF-1-dependent repression of adenosine kinase attenuates hypoxia-induced vascular leak. Blood (2008) 111:5571-80. doi: 10.1182/blood-2007-11-126763

33. Narravula S, Lennon PF, Mueller BU, Colgan SP. Regulation of endothelial CD73 by adenosine: paracrine pathway for enhanced endothelial barrier function. $J$ Immunol (2000) 165:5262-8. doi: 10.4049/jimmunol.165.9.5262

34. Eckle T, Fullbier L, Wehrmann M, Khoury J, Mittelbronn M, Ibla J, et al. Identification of ectonucleotidases $\mathrm{CD} 39$ and $\mathrm{CD} 73$ in innate protection during acute lung injury. J Immunol (2007) 178:8127-37. doi: 10.4049/jimmunol.178.12.8127

35. Louis NA, Robinson AM, MacManus CF, Karhausen J, Scully M, Colgan SP. Control of IFN-alphaA by CD73: implications for mucosal inflammation. Jimmunol (2008) 180:4246-55. doi: 10.4049/jimmunol.180.6.4246

36. Ohtsuka T, Changelian PS, Bouis D, Noon K, Harada H, Lama VN, et al. Ecto$5^{\prime}$-nucleotidase $(\mathrm{CD} 73)$ attenuates allograft airway rejection through adenosine 2A receptor stimulation. J Immunol (2010) 185:1321-9. doi: 10.4049/ jimmunol.0901847

37. Tsukamoto H, Chernogorova P, Ayata K, Gerlach UV, Rughani A, Ritchey JW, et al. Deficiency of CD73/ecto-5' -nucleotidase in mice enhances acute graft-versus-host disease. Blood (2012) 119:4554-64. doi: 10.1182/blood-2011-09-375899

38. Jarvis MF, Yu H, McGaraughty S, Wismer CT, Mikusa J, Zhu C, et al. Analgesic and anti-inflammatory effects of A-286501, a novel orally active adenosine kinase inhibitor. Pain (2002) 96:107-18. doi: 10.1016/S0304-3959(01)00435-3

39. Laghi-Pasini F, Guideri F, Petersen C, Lazzerini PE, Sicari R, Capecchi PL, et al. Blunted increase in plasma adenosine levels following dipyridamole stress in dilated cardiomyopathy patients. J Intern Med (2003) 254:591-6. doi: 10.1111/j.1365-2796.2003.01234.x

40. Rudensky AY. Regulatory T cells and Foxp3. Immunol Rev (2011) 241:260-8. doi: 10.1111/j.1600-065X.2011.01018.x

41. Ohkura N, Kitagawa Y, Sakaguchi S. Development and maintenance of regulatory T cells. Immunity (2013) 38:414-23. doi: 10.1016/j.immuni.2013.03.002

42. Ernst PB, Garrison JC, Thompson LF. Much ado about adenosine: adenosine synthesis and function in regulatory T cell biology. J Immunol (2010) 185:1993-8. doi: 10.4049/jimmunol.1000108

43. Whiteside TL, Jackson EK. Adenosine and prostaglandin e2 production by human inducible regulatory T cells in health and disease. Front Immunol (2013) 4:212. doi: 10.3389/fimmu.2013.00212

44. Kobie JJ, Shah PR, Yang L, Rebhahn JA, Fowell DJ, Mosmann TR. T regulatory and primed uncommitted $\mathrm{CD} 4 \mathrm{~T}$ cells express $\mathrm{CD} 73$, which suppresses effector CD4 T cells by converting $5^{\prime}$-adenosine monophosphate to adenosine. Jmmunol (2006) 177:6780-6. doi: 10.4049/jimmunol.177.10.6780

45. Deaglio S, Dwyer KM, Gao W, Friedman D, Usheva A, Erat A, et al. Adenosine generation catalyzed by CD39 and CD73 expressed on regulatory T cells mediates immune suppression. J Exp Med (2007) 204:1257-65. doi: 10.1084/ jem. 20062512

46. Mandapathil M, Szczepanski MJ, Szajnik M, Ren J, Lenzner DE, Jackson EK, et al. Increased ectonucleotidase expression and activity in regulatory T cells of patients with head and neck cancer. Clin Cancer Res (2009) 15:6348-57. doi: 10.1158/10780432.CCR-09-1143

47. Mandapathil M, Hilldorfer B, Szczepanski MJ, Czystowska M, Szajnik M, Ren J, et al. Generation and accumulation of immunosuppressive adenosine by human CD4+CD25highFOXP3+ regulatory T cells. J Biol Chem (2010) 285:7176-86. doi: 10.1074/jbc.M109.047423

48. Kinsey GR, Huang L, Jaworska K, Khutsishvili K, Becker DA, Ye H, et al. Autocrine adenosine signaling promotes regulatory $\mathrm{T}$ cell-mediated renal protection. J Am Soc Nephrol (2012) 23:1528-37. doi: 10.1681/ASN.2012010070 
49. Hesdorffer CS, Malchinkhuu E, Biragyn A, Mabrouk OS, Kennedy RT, Madara $\mathrm{K}$, et al. Distinctive immunoregulatory effects of adenosine on T cells of older humans. FASEB J (2012) 26:1301-10. doi: 10.1096/fj.11-197046

50. Bopp T, Becker C, Klein M, Klein-Hessling S, Palmetshofer A, Serfling E, et al. Cyclic adenosine monophosphate is a key component of regulatory T cell-mediated suppression. J Exp Med (2007) 204:1303-10. doi: 10.1084/jem.20062129

51. Gri G, Piconese S, Frossi B, Manfroi V, Merluzzi S, Tripodo C, et al. CD4+CD25+ regulatory $\mathrm{T}$ cells suppress mast cell degranulation and allergic responses through OX40-OX40L interaction. Immunity (2008) 29:771-81. doi: 10.1016/j. immuni.2008.08.018

52. Yaqub S, Tasken K. Role for the cAMP-protein kinase A signaling pathway in suppression of antitumor immune responses by regulatory T cells. Crit Rev Oncog (2008) 14:57-77. doi: 10.1615/CritRevOncog.v14.i1.40

53. Mandapathil M, Szczepanski MJ, Szajnik M, Ren J, Jackson EK, Johnson JT, et al. Adenosine and prostaglandin E2 cooperate in the suppression of immune responses mediated by adaptive regulatory T cells. J Biol Chem (2010) 285:27571-80. doi: 10.1074/jbc.M110.127100

54. Ehrentraut H, Clambey ET, McNamee EN, Brodsky KS, Ehrentraut SF, Poth JM, et al. CD73+ regulatory $\mathrm{T}$ cells contribute to adenosine-mediated resolution of acute lung injury. FASEB J (2013) 27:2207-19. doi: 10.1096/fj.12-225201

55. Wang L, Fan J, Chen S, Zhang Y, Curiel TJ, Zhang B. Graft-versus-host disease is enhanced by selective CD73 blockade in mice. PLoS One (2013) 8:e58397. doi: 10.1371/journal.pone.0058397

56. Ring S, Oliver SJ, Cronstein BN, EnkAH, Mahnke K. CD4+CD25+regulatory T cells suppress contact hypersensitivity reactions through a CD39, adenosine-dependent mechanism. JAllergy Clin Immunol (2009) 123(1287-1296):e1282. doi: 10.1016/j. jaci.2009.03.022

57. Nikolova M, Carriere M, Jenabian MA, Limou S, Younas M, Kok A, et al. CD39/ adenosine pathway is involved in AIDS progression. PLoS Pathog (2011) 7:e1002110. doi: 10.1371/journal.ppat.1002110

58. Naganuma M, Wiznerowicz EB, Lappas CM, Linden J, Worthington MT, Ernst PB. Cutting edge: critical role for A2A adenosine receptors in the T cell-mediated regulation of colitis. J Immunol (2006) 177:2765-9. doi: 10.4049/jimmunol.177.5.2765

59. Sitkovsky MV. T regulatory cells: hypoxia-adenosinergic suppression and re-direction of the immune response. Trends Immunol (2009) 30:102-8. doi: 10.1016/j. it.2008.12.002

60. Ben-Shoshan J, Maysel-Auslender S, Mor A, Keren G, George J. Hypoxia controls CD4+CD25+ regulatory T-cell homeostasis via hypoxia-inducible factor-1 alpha. Eur J Immunol (2008) 38:2412-8. doi: 10.1002/eji.200838318

61. Dang EV, Barbi J, Yang HY, Jinasena D, Yu H, Zheng Y, et al. Control of T(H)17/ $\mathrm{T}$ (reg) balance by hypoxia-inducible factor 1. Cell (2011) 146:772-84. doi: 10.1016/j.cell.2011.07.033

62. Shi LZ, Wang R, Huang G, Vogel P, Neale G, Green DR, et al. HIF1alphadependent glycolytic pathway orchestrates a metabolic checkpoint for the differentiation of TH17 and Treg cells. J Exp Med (2011) 208:1367-76. doi: 10.1084 /jem.20110278

63. Clambey ET, McNamee EN, Westrich JA, Glover LE, Campbell EL, Jedlicka P, et al. Hypoxia-inducible factor-1 alpha-dependent induction of FoxP3 drives regulatory T-cell abundance and function during inflammatory hypoxia of the mucosa. Proc Natl Acad Sci U S A (2012) 109:E2784-93. doi: 10.1073/pnas.1202366109

64. Ohta A, Kini R, Ohta A, Subramanian M, Madasu M, Sitkovsky M. The development and immunosuppressive functions of CD4(+) CD25(+) FoxP3(+) regulatory T cells are under influence of the adenosine-A2A adenosine receptor pathway. Front Immunol (2012) 3:190. doi: 10.3389/fimmu.2012.00190

65. Han KL, Thomas SV, Koontz SM, Changpriroa CM, Ha SK, Malech HL, et al. Adenosine A(2)A receptor agonist-mediated increase in donor-derived regulatory T cells suppresses development of graft-versus-host disease. J Immunol (2013) 190:458-68. doi: 10.4049/jimmunol.1201325

66. Lee DJ, Taylor AW. Both MC5r and A2Ar are required for protective regulatory immunity in the spleen of post-experimental autoimmune uveitis in mice. $J$ Immunol (2013) 191:4103-11. doi: 10.4049/jimmunol.1300182

67. Becker C, Taube C, Bopp T, Becker C, Michel K, Kubach J, et al. Protection from graft-versus-host disease by HIV-1 envelope protein gp120-mediated activation of human CD4+CD25+ regulatory T cells. Blood (2009) 114:1263-9. doi: 10.1182/ blood-2009-02-206730

68. Guereschi MG, Araujo LP, Maricato JT, Takenaka MC, Nascimento VM, Vivanco $\mathrm{BC}$, et al. Beta2-adrenergic receptor signaling in CD4+ Foxp3+ regulatory T cells enhances their suppressive function in a PKA-dependent manner. Eur J Immunol (2013) 43:1001-12. doi: 10.1002/eji.201243005

69. Bodor J, Bopp T, Vaeth M, Klein M, Serfling E, Hunig T, et al. Cyclic AMP underpins suppression by regulatory T cells. Eur J Immunol (2012) 42:1375-84. doi: 10.1002/ eji.201141578

70. Klein M, Vaeth M, Scheel T, Grabbe S, Baumgrass R, Berberich-Siebelt F, et al. Repression of cyclic adenosine monophosphate upregulation disarms and expands human regulatory T cells. J Immunol (2012) 188:1091-7. doi: 10.4049/ jimmunol.1102045

71. Bacher N, Raker V, Hofmann C, Graulich E, Schwenk M, Baumgrass R, et al. Interferon-alpha suppresses cAMP to disarm human regulatory T cells. Cancer Res (2013) 73:5647-56. doi: 10.1158/0008-5472.CAN-12-3788

72. Cadieux JS, Leclerc P, St-Onge M, Dussault AA, Lafl amme C, Picard S, et al. Potentiation of neutrophil cyclooxygenase- 2 by adenosine: an early anti-inflammatory signal. J Cell Sci (2005) 118:1437-47. doi: 10.1242/jcs.01737

73. Zarek PE, Huang CT, Lutz ER, Kowalski J, Horton MR, Linden J, et al. A2A receptor signaling promotes peripheral tolerance by inducing T-cell anergy and the generation of adaptive regulatory T cells. Blood (2008) 111:251-9. doi: 10.1182/ blood-2007-03-081646

74. Ehrentraut H, Westrich JA, Eltzschig HK, Clambey ET. Adora2b adenosine receptor engagement enhances regulatory $\mathrm{T}$ cell abundance during endotoxin-induced pulmonary inflammation. PLoS One (2012) 7:e32416. doi: 10.1371/journal. pone.0032416

75. Pozo D, Anderson P, Gonzalez-Rey E. Induction of alloantigen-specific human T regulatory cells by vasoactive intestinal peptide. J Immunol (2009) 183:4346-59. doi: 10.4049/jimmunol.0900400

76. Sauer AV, Brigida I, Carriglio N, Hernandez RJ, Scaramuzza S, Clavenna D, et al. Alterations in the adenosine metabolism and CD39/CD73 adenosinergic machinery cause loss of Treg cell function and autoimmunity in ADA-deficient SCID. Blood (2012) 119:1428-39. doi: 10.1182/blood-2011-07-366781

77. Regateiro FS, Howie D, Nolan KF, Agorogiannis EI, Greaves DR, Cobbold SP, et al. Generation of anti-inflammatory adenosine by leukocytes is regulated by TGF-beta. Eur J Immunol (2011) 41:2955-65. doi: 10.1002/eji.201141512

78. Chalmin F, Mignot G, Bruchard M, Chevriaux A, Vegran F, Hichami A, et al. Methotrexate - how does it really work? Nat Rev Rheumatol (2010) 6:175-8. doi: 10.1038/nrrheum.2010.5

79. Carneiro-Ramos MS, Da Silva VB, Coutinho MB Jr, Battastini AM, Sarkis JJ, Barreto-Chaves ML. Thyroid hormone stimulates $5^{\prime}$-ecto-nucleotidase of neonatal rat ventricular myocytes. Mol Cell Biochem (2004) 265:195-201. doi: 10.1023/B:MCBI.0000044396.31443.a8

80. Niemela J, Henttinen T, Yegutkin GG, Airas L, Kujari AM, Rajala P, et al. IFN-alpha induced adenosine production on the endothelium: a mechanism mediated by CD73 (ecto-5' -nucleotidase) up-regulation. J Immunol (2004) 172:1646-53. doi: 10.4049/jimmunol.172.3.1646

81. Bernardi A, Bavaresco L, Wink MR, Jacques-Silva MC, Delgado-Canedo A, Lenz $\mathrm{G}$, et al. Indomethacin stimulates activity and expression of ecto- $5^{\prime}$-nucleotidase/ CD73 in glioma cell lines. Eur J Pharmacol (2007) 569:8-15. doi: 10.1016/j. ejphar.2007.04.058

82. Meijer P, Oyen WJ, Dekker D, Van Den Broek PH, Wouters CW, Boerman OC, et al. Rosuvastatin increases extracellular adenosine formation in humans in vivo: a new perspective on cardiovascular protection. Arterioscler Thromb Vasc Biol (2009) 29:963-8. doi: 10.1161/ATVBAHA.108.179622

83. Montesinos MC, Yap JS, Desai A, Posadas I, McCrary CT, Cronstein BN. Reversal of the antiinflammatory effects of methotrexate by the nonselective adenosine receptor antagonists theophylline and caffeine: evidence that the antiinflammatory effects of methotrexate are mediated via multiple adenosine receptors in rat adjuvant arthritis. Arthritis Rheum (2000) 43:656-63. doi: 10.1002/1529-0131(200003)43:3<656::AID-ANR23>3.0.CO;2-H

84. Chan ES, Cronstein BN. Methotrexate-how does it really work? Nat Rev Rheumatol (2010) 6:175-8. doi: 10.1038/nrrheum.2010.5

85. Gadangi P, Longaker M, Naime D, Levin RI, Recht PA, Montesinos MC, et al. The anti-inflammatory mechanism of sulfasalazine is related to adenosine release at inflamed sites. J Immunol (1996) 156:1937-41.

86. Morabito L, Montesinos MC, Schreibman DM, Balter L, Thompson LF, Resta R, et al. Methotrexate and sulfasalazine promote adenosine release by a mechanism that requires ecto- $5^{\prime}$-nucleotidase-mediated conversion of adenine nucleotides. J Clin Invest (1998) 101:295-300. doi: 10.1172/JCI1554 
87. Kim YC, Kim KK, Shevach EM. Simvastatin induces Foxp3+ T regulatory cells by modulation of transforming growth factor-beta signal transduction. Immunology (2010) 130:484-93. doi: 10.1111/j.1365-2567.2010.03269.x

88. Tang TT, Song Y, Ding YJ, Liao YH, Yu X, Du R, et al. Atorvastatin upregulates regulatory $\mathrm{T}$ cells and reduces clinical disease activity in patients with rheumatoid arthritis. J Lipid Res (2011) 52:1023-32. doi: 10.1194/jlr.M010876

89. Hilbrands R, Howie D, Cobbold S, Waldmann H. Regulatory T cells and transplantation tolerance. Immunotherapy (2013) 5:717-31. doi: 10.2217/imt.13.69

90. Singer BD, King LS, D’Alessio FR. Regulatory T cells as immunotherapy. Front Immunol (2014) 5:46. doi: 10.3389/fimmu.2014.00046

91. Blazar BR, Murphy WJ, Abedi M. Advances in graft-versus-host disease biology and therapy. Nat Rev Immunol (2012) 12:443-58. doi: 10.1038/nri3212

92. Kerkar SP, Restifo NP. Cellular constituents of immune escape within the tumor microenvironment. Cancer Res (2012) 72:3125-30. doi: 10.1158/0008-5472. CAN-11-4094

93. Blay J, White TD, Hoskin DW. The extracellular fluid of solid carcinomas contains immunosuppressive concentrations of adenosine. Cancer Res (1997) 57:2602-5.

94. Ohta A, Gorelik E, Prasad SJ, Ronchese F, Lukashev D, Wong MK, et al. A2A adenosine receptor protects tumors from antitumor T cells. Proc Natl Acad Sci U S A (2006) 103:13132-7. doi: 10.1073/pnas.0605251103

95. Brown JM, Wilson WR. Exploiting tumour hypoxia in cancer treatment. Nat Rev Cancer (2004) 4:437-47. doi: 10.1038/nrc1367

96. Vaupel P, Mayer A. Hypoxia in cancer: significance and impact on clinical outcome. Cancer Metastasis Rev (2007) 26:225-39. doi: 10.1007/s10555-007-9055-1

97. Ryzhov S, Novitskiy SV, Zaynagetdinov R, Goldstein AE, Carbone DP, Biaggioni $\mathrm{I}$, et al. Host A(2B) adenosine receptors promote carcinoma growth. Neoplasia (2008) 10:987-95. doi: 10.1593/neo.08478

98. Cekic C, Sag D, Li Y, Theodorescu D, Strieter RM, Linden J. Adenosine A2B receptor blockade slows growth of bladder and breast tumors. J Immunol (2012) 188:198-205. doi: 10.4049/jimmunol.1101845

99. Zhang B. CD73: a novel target for cancer immunotherapy. Cancer Res (2010) 70:6407-11. doi: 10.1158/0008-5472.CAN-10-1544

100. Beavis PA, Stagg J, Darcy PK, Smyth MJ. CD73: a potent suppressor of antitumor immune responses. Trends Immunol (2012) 33:231-7. doi: 10.1016/j.it.2012.02.009

101. Ryzhov S, Novitskiy SV, Goldstein AE, Biktasova A, Blackburn MR, Biaggioni I, et al. Adenosinergic regulation of the expansion and immunosuppressive activity of CD11b+Gr1+cells. JImmunol (2011) 187:6120-9. doi: 10.4049/jimmunol.1101225

102. Jin D, Fan J, Wang L, Thompson LF, Liu A, Daniel BJ, et al. CD73 on tumor cells impairs antitumor T-cell responses: a novel mechanism of tumor-induced immune suppression. Cancer Res (2010) 70:2245-55. doi: 10.1158/0008-5472.CAN-09-3109

103. Waickman AT, Alme A, Senaldi L, Zarek PE, Horton M, Powell JD. Enhancement of tumor immunotherapy by deletion of the A2A adenosine receptor. Cancer Immunol Immunother (2012) 61:917-26. doi: 10.1007/s00262-011-1155-7
104. Stagg J, Divisekera U, McLaughlin N, Sharkey J, Pommey S, Denoyer D, et al. Anti-CD73 antibody therapy inhibits breast tumor growth and metastasis. Proc Natl Acad Sci U S A (2010) 107:1547-52. doi: 10.1073/pnas.0908801107

105. Huang S, Apasov S, Koshiba M, Sitkovsky M. Role of A2a extracellular adenosine receptor-mediated signaling in adenosine-mediated inhibition of T-cell activation and expansion. Blood (1997) 90:1600-10.

106. Sevigny CP, Li L, Awad AS, Huang L, McDuffie M, Linden J, et al. Activation of adenosine $2 \mathrm{~A}$ receptors attenuates allograft rejection and alloantigen recognition. J Immunol (2007) 178:4240-9. doi: 10.4049/jimmunol.178.7.4240

107. Linnemann C, Schildberg FA, Schurich A, Diehl L, Hegenbarth SI, Endl E, et al. Adenosine regulates CD8 T-cell priming by inhibition of membraneproximal T-cell receptor signalling. Immunology (2009) 128:e728-37. doi: 10.1111/j.1365-2567.2009.03075.x

108. Raskovalova T, Lokshin A, Huang X, Su Y, Mandic M, Zarour HM, et al. Inhibition of cytokine production and cytotoxic activity of human antimelanoma specific CD8+ and CD4+ T lymphocytes by adenosine-protein kinase A type I signaling. Cancer Res (2007) 67:5949-56. doi: 10.1158/0008-5472.CAN-06-4249

109. Ohta A, Ohta A, Madasu M, Kini R, Subramanian M, Goel N, et al. A2A adenosine receptor may allow expansion of $\mathrm{T}$ cells lacking effector functions in extracellular adenosine-rich microenvironments. Jimmunol (2009) 183:5487-93. doi: 10.4049/ jimmunol.0901247

110. Hofer S, Ivarsson L, Stoitzner P, Auffinger M, Rainer C, Romani N, et al. Adenosine slows migration of dendritic cells but does not affect other aspects of dendritic cell maturation. J Invest Dermatol (2003) 121:300-7. doi: 10.1046/j.1523-1747.2003.12369.x

111. Hasko G, Linden J, Cronstein B, Pacher P. Adenosine receptors: therapeutic aspects for inflammatory and immune diseases. Nat Rev Drug Discov (2008) 7:759-70. doi: $10.1038 / \mathrm{nrd} 2638$

Conflict of Interest Statement: The authors declare that the research was conducted in the absence of any commercial or financial relationships that could be construed as a potential conflict of interest.

Received: 08 March 2014; paper pending published: 05 April 2014; accepted: 15 June 2014; published online: 10 July 2014.

Citation: Ohta A and Sitkovsky M (2014) Extracellular adenosine-mediated modulation of regulatory T cells. Front. Immunol. 5:304. doi: 10.3389/fimmu.2014.00304

This article was submitted to the journal Frontiers in Immunology.

Copyright (C) 2014 Ohta and Sitkovsky. This is an open-access article distributed under the terms of the Creative Commons Attribution License (CC BY). The use, distribution or reproduction in other forums is permitted, provided the original author(s) or licensor are credited and that the original publication in this journal is cited, in accordance with accepted academic practice. No use, distribution or reproduction is permitted which does not comply with these terms. 